\title{
Journal of Health Ethics
}

Volume 1 | Issue 1

Article 7

2004

\section{"Forward" Commentary}

Sheila P. Davis Ph.D., RN

Online Journal of Health Ethics Editor-in-Chief

Follow this and additional works at: https://aquila.usm.edu/ojhe

\section{Recommended Citation}

Davis, S. P. (2004). "Forward" Commentary. Journal of Health Ethics, 1(1). http://dx.doi.org/ 10.18785/ojhe.0101.07

This Front Matter is brought to you for free and open access by The Aquila Digital Community. It has been accepted for inclusion in Journal of Health Ethics by an authorized editor of The Aquila Digital Community. For more information, please contact Joshua.Cromwell@usm.edu. 


\section{Online Journal of Health Ethics Commentary}

\section{"Forward"}

The Online Journal of Health Ethics, the newest voice on ethical health related issues, presents as both complementary and unique when compared to existing ethical health publications. As founder and editorin-chief of the journal, I am an African-American female with a lived experience of being on the "other" side of health care. As such, issues such as access to care, health disparities, allocation of care, quality of life, vulnerable populations, end of life, ethnic minority health, health policy, spiritual care, and research ethics, etc. are first approached with the mindset of ensuring equity as opposed to deciding if equity is warranted. The underlying premise is that ethical care is equitable care. One cannot exist without the other. In other words, red, brown, yellow, black and white, all are precious.

Having served a three year term on the Institute of Medicine (IOM) Consequences of Uninsurance Committee and receiving a lifetime associate membership into the National Academies, I was further convinced of a need to create a venue to publicize inequities existing in health due to circumstances beyond the control of the individual. More than 80 percent of uninsured children and adults under the age of 65 live in working families. An online journal emerged as the most expedient way in which to inform of these and other inequities which result in unequal treatment in health care. This type of format also permits the input and feedback of readers across the spectrum of professions and vocations.

Special thanks are extended to the University of Mississippi Medical Center for endorsing the journal and providing unquestioning support for its operation. The journal is hosted free of charge on the University of Mississippi Medical Center server. Thanks are also extended to the John D. Bower Foundation for funding the grant to launch the journal and providing a member of the advisory board. To the associate editors, reviewers, the advisory board members, authors, subscribers and students of ethics, thank you. Lastly, words are inadequate to express the gratitude I feel for both Henk de Weerdt, webmaster and Barbara Austin, Director of Public Affairs, for expending efforts beyond the call of duty in your support.

To our colleague publications, the American Journal of Bioethics ( the nation's first online bioethics journal), Nursing Ethics, and other ethics journals, thank you for creating a forum and an appetite for discussion of ethics in health. We now humbly join you in this mandate. I claim the promise of Ephesians $3: 20$, as we add our voice to the dialogue and debates informing ethics in health.

Sheila P. Davis, PhD, R.N.

Editor-in-Chief, Online Journal of Health Ethics 